International Journal of Instruction e-ISSN: 1308-1470 • www.e-iji.net

Article submission code: 20191228150444

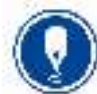

January $2021 \bullet$ Vol.14, No.1

p-ISSN: 1694-609X

pp. $235-252$

Received: 28/12/2019

Revision: 15/06/2020
Accepted: 06/07/2020

OnlineFirst: 11/10/2020

\title{
Pancasila Economic Character Literacy Program for High School Students
}

\author{
Agussalim \\ Doctoral Student of Universitas Negeri Malang, Lecturer in STKIP Bima, Indonesia, \\ agussalimmpd08@gmail.com
}

Sri Umi Mintarti Widjaja

Universitas Negeri Malang, Indonesia, sri.umi.fe@um.ac.id

\author{
Agung Haryono \\ Universitas Negeri Malang, Indonesia, agung.haryono.fe@um.ac.id
}

\section{Hari Wahyono}

Universitas Negeri Malang, Indonesia,hari.wahyono.fe@um.ac.id

The economic system of a nation depends on the ideology that is governed as well as the State of Indonesia. Pancasila Economy is an economic system based on Pancasila values. The values of Pancasila in the economy include caring, brotherhood, nationalism, and economic justice. This study aims to improve the knowledge, attitudes and economic behavior of Pancasila-based students through the "Pancasila economic character literacy program integrated with the community and parents through cooperative learning type Student Teams-Achievement Divisions (STAD) and Group Investigation (GI). This research is classified into action research with research subjects of State Senior High School 2 Soromandi Bima, West Nusa Tenggara-Indonesia Province, amounting to 84 people. Data collection techniques using essay questions, questionnaires and the mini economy canteen of Pancasila. Data were analyzed using quantitative descriptive analysis. The results showed that the Pancasila Economic Character Literacy Program can improve the knowledge, attitudes and economic behavior of students based on Pancasila values in daily life. Therefore educational institutions must develop superior programs based on the ideology that fosters students' economic character in accordance with national identity.

Keywords: program, literacy, character, economic, pancasila, high school

\section{INTRODUCTION}

The economic system adopted by a nation (state or group of people) depends on the doctrine, or the flow of economic views is influenced by the self of values embraced by a nation such as habits, customs, norms, and ideologies that will give birth to a

Citation: Agussalim., Widjaja, S. U. M., Haryono, A., \& Wahyono, H. (2021). Pancasila Economic Character Literacy Program for High School Students. International Journal of Instruction, 14(1), 235-252. https://doi.org/10.29333/iji.2021.14114a 
consensus in the form of an agreement on shared goals and orientation to direct existing resources for common goals. The most fundamental in the economic system is the basic values that are ideological and above those basic values, the economic system will subsequently become the foundation that colors and animates all components of the economic system (Deliarnov, 2012). Pancasila as the ideology of the Indonesian State which is extracted from the noble values of the nation becomes a reference for thinking, acting and behaving for the Indonesian people in the nation and state, concretely in managing and utilizing resources must be guided by the values of the Pancasila.

Pancasila is the official philosophical foundation of the Indonesian state. Pancasila consists of two old Javanese words (originally from Sanskrit): "pañca" meaning five, and "sīla" meaning principles. It comprises five principles held to be inseparable and interrelated: (1) Belief in the one and only God (in Indonesian, Ketuhanan Yang Maha Esa). (2) Just and civilised humanity (in Indonesian, Kemanusiaan yang Adil dan Beradab). (3) The Unity of Indonesia (in Indonesian, Persatuan Indonesia). (4) Democracy guided by the inner wisdom in the unanimity arising out of deliberations amongst representatives (in Indonesian, Kerakyatan Yang Dipimpin oleh Hikmat Kebijaksanaan dalam Permusyawaratan dan Perwakilan). (5) Social justice for all of the people of Indonesia (in Indonesian, Keadilan Sosial bagi seluruh Rakyat Indonesia). (Jaelani, 2016)

In the economic perspective, the five precepts are a series of systems (interconnected series); the first and second precepts constitute "Input", the third and fourth precepts as "Process" and the fifth precept is "Output" of all Indonesian economic policies (macro and micro). It can be understood Pancasila Economy is an economic system that refers to Pancasila values and is oriented on fair and equitable economic welfare for all Indonesian people. Pancasila economy is not stimulated to achieve economic goals only; not only the motive of maximizing profit and economic satisfaction but also concerning social, cultural and religious motives. The Pancasila economy is balancing and accommodating between common interests and individual interests, but still prioritizing independence in togetherness to build, accelerate and strengthen the growth of the national economy (Mubyarto, 2004).

The term Pancasila Economy first appeared in 1967 in an article written by Dr. Emil Salim and became clearer when in 1979 Emil Salim discussed again what was meant by "Pancasila Economy". Its essence is a concept of economic wisdom after experiencing movement like a pendulum clock from left to right until it reaches a balance point. To the right means to be free to follow the market and neoclassical rules, while to the left means to experience state intervention in the form of centralized planning (socialist or communist). Then in 1981 Prof. Mubyarto brought Pancasila Economy discussion in the world of Indonesian campuses (Tjakrawerdaja \& Soedarno, 2017). The Pancasila economy is not new either in terms of its philosophical or application, it has actually been practiced in real economic policy since Indonesia's independence because the values of the Pancasila Economy existed before the Indonesian Nation was declared independence. These values are set forth in the 1945 Constitution of the State of the Republic of Indonesia Article 33 and 34 (Mubyarto, 2004). 
The fact is now that the Indonesian economic system has been dominated by neoclassical-neoliberal understandings that have proven to be incompatible with the values of Pancasila as the nation's identity. Therefore, there needs to be a systematic and organized revitalization movement in order to understand the Pancasila Economy as a host in Indonesia (Subroto, 2015). Revitalization movement can be done by teaching the nation's children about Pancasila Economic values and their application in daily life through economic education. Economic material is not only transferring knowledge but also as a media for inculcating ideological values (Ilyas \& Tahir, 2015). Values are part of the reality of human life that need to be considered in the development process, especially by educational institutions. Separation of ethical values with economics makes the destruction of economics because essentially ethical and economic values are one entity, and both are separated after the emergence of neoclassical economic theory but lately many works of literature that update the relationship between ethical values and economics (Gasper, 2008; Morgan, 2013).

The economics taught in Indonesia must be integrated with the values of Pancasila, namely: (1) economic care is related to actions that provide benefits and actions that avoid things that harm others (Singer \& Snower, 2010); (2) brotherhood implies that all economic actors are believed to be compared to one family household (Swasono. 2015); 3) nationalism is understood as membership awareness in a nation that is potential or actual to achieve and maintain the shared identity and prosperity of other nations (Fölster, 2013); and (4) Economic justice implies sharing with the principle of equality, the principle of distributive justice, and the principle of contributing justice (Boylan, 2015). Unfortunately, these values are very minimal taught in schools, precisely without the risk of economic risk that is taught at all levels of Indonesian education is dominated by theories and practices of neoclassical or capitalist economics (Mubyarto, 2004; Swasono, 2015; Ilyas \& Tahir, 2015).

Such conditions not only occur in Indonesia but also in several other countries such as in Arabia, Malaysia and China there are even special agents responsible for systematically spreading and maintaining hegemony including through reference and management of education management (Hanafiah, 2016; Neal \& Finlay, 2008; Jamil, 2015; Schmidtke \& Chen, 2012). Neoclassical economic teaching has an effect on the personality of children who are materialist, individualist, tend to ignore spiritual capital, high antisocial behavior, undermine economic morals, are unrealistic, and significantly less supportive of egalitarian solutions when compared to students and instructors of other majors or education because neoclassical ideas are proven inhuman (Adams, 2019; Bauman \& Rose, 2011; Boylan, 2015; Eisler, 2010; Etzioni, 2015; Faravelli, 2007; Lucey, 2019).

Teaching neoclassical economics or capitalism indirectly affects the high index of economic inequality. Inequality between all people in the world has declined since 1990, but within-country inequality is still higher today than 25 years ago, which means that an average person today is more likely to live in an economy with higher inequality compared to 25 years ago (Word Bank, 2019). In Indonesia from 2003 to 2010, that 10 percent of the richest households in Indonesia increased consumption by 6 percent per year, while 40 percent of poor households, their consumption level decreased by 2 
percent per year with this Gini ratio, ie from 30 percent on in 2000 to 41 percent in 2013 (World Bank, 2015). In March 2019 the level of inequality in expenditure of the Indonesian population as measured by the Gini ratio was 0.382 (Badan Pusat Statisitik, 2019).

The results of a preliminary study in West Nusa Tenggara Province-Indonesia using questionnaires, interviews and social experiments found several things: (1) Distributing questionnaires to 186 respondents consisting of students, teachers and economics lecturers, it is known that $76 \%$ of respondents have and or have heard of the Economics of Production, and as many as $24 \%$ have never heard of the term Pancasila Economy. Respondents' understanding of the Pancasila Economy by $82 \%$ only knows as an economic system that is indicative of mutual cooperation activities, while $18 \%$ only has only heard of it. $41 \%$ assess Pancasila Economic values have not been applied at all in economic learning in schools, $31 \%$ of respondents assess only partially applied, and $29 \%$ answered have been applied. There are 35\% of respondents assessing the value of the Pancasila Economy is still applied in the community, there are 17\% said no at all, and $48 \%$ answered sometimes applied. (2) Distributing questionnaires filled out by 374 high school students regarding the application of the Pancasila Economic values in daily life the results were $83 \%$ each time the school graduation announcement would strike uniformly, $9 \%$ answered doubtfully, and $8 \%$ answered will give to the juniors. When there was a classmate or his parents were treated at the nearest hospital there were $74 \%$ answered they had never visited, 19\% had visited, and 7\% often visited. (3) The results of an interview with the owner of the school canteen every time the food system is used first and then paid by the seller often loses because someone pays less than the amount eaten. (4) The results of the Pancasila Mini Economy Canteen Expansion by selling several types and amounts of snacks, but no one is looking after them. The buyer/student will take and pay for themselves by entering the money in the place provided by the researcher. The results of the experiment for 30 days in aggregate experienced a very high transaction devisit.

The Indonesian nation is experiencing a moral crisis and a solution must be found. From the results of the Focus Group Discussion (FGD) with economics teachers, students' parents and community leaders agreed: First, there must be a special extra-curricular program to foster the economic character of children. So far, many schools have found implementing extra-curricular excellent programs such as foreign language skills development programs, but there are no special programs for fostering economic character. This solution is also based on the results of previous research analyzes which prove various models and types of excellent programs both in the economic and psychological fields show effective results (Amagir et al., 2018, 2019; Leptien, 2015; Vaknin \& Bresciani, 2013).

Second, economic learning in schools must be integrated with the community and parents because so far economic learning tends to be theoretical (texs books), as an impact students find it difficult to connect between theory and economic activity in their respective environments. Therefore we need cooperative learning type Student TeamsAchievement Divisions (STAD) and Group Investigation (GI); learning using STAD 
and GI can improve learning outcomes, togetherness, motivation to learn in economic education (Arinda et al., 2019; Wyk, 2012; Yuliani, 2019).

The program developed is Pancasila Economic Character Literacy Program integrated with the community and parents through cooperative learning Type STAD and GI. The application of STAD and GI is done by assigning students to conduct field observations about the application of the Pancasila Economic values in the community and their respective families, then the results of these observations become discussion material in class.

During this time the role of community or educational leaders and parents is passive in the administration of education in schools due to the disintegration of the informal, formal and non-formal education channels. Programs that are integrated with the environment, society and people are proven to be successful in achieving the objectives of educational programs especially in improving social skills and financial literacy of students (Jayaraman \& Jambunathan, 2018; Riccio \& Hannon, 2002).

The research action hypothesis of the Pancasila Economic Character Literacy Program integrated with the community and parents through Cooperative Learning Type STAD and GI can improve the knowledge, attitudes and economic behavior of students based on Pancasila values in daily life. 


\section{Program Syllabus Structure}

Table 1

Competency standards: theoretically understanding the pancasila economy and its application in daily life

\begin{tabular}{|c|c|c|}
\hline Basic & Indicator & Pancasila \\
\hline Competencies & Matter & Economic Values \\
\hline
\end{tabular}

1. Theoretically Understanding the Pancasila Economy manifested in the 1945 Constitution of the State of the Republic of Indonesia Articles 33 and 34.

\begin{tabular}{|c|c|c|}
\hline $\begin{array}{l}\text { 1. Pancasila } \\
\text { Economic } \\
\text { Concepts }\end{array}$ & $\begin{array}{l}\text { 1.1 Describe the ability to conclude the definition of Pancasila } \\
\text { Economy. } \\
\text { 1.2 Analyze the characteristics of the Pancasila Economy } \\
\text { associated with the implementation of its policies. }\end{array}$ & $\begin{array}{l}\text { 1. Caring } \\
\text { 2. Brotherhood } \\
\text { 3. Nationalism } \\
\text { 4. Justice }\end{array}$ \\
\hline $\begin{array}{l}\text { 2. Internalization of } \\
\text { the Pancasila } \\
\text { Economy }\end{array}$ & $\begin{array}{l}\text { 2.1 Analyzing Pancasila in an economic perspective. } \\
\text { 2.2 Formulating a 'system' of Pancasila Economy with the ability } \\
\text { to abstract the form of mindset. }\end{array}$ & \\
\hline $\begin{array}{l}\text { 3. Joint ventures } \\
\text { based on family } \\
\text { principles }\end{array}$ & $\begin{array}{l}\text { 3.1 Analyze business actors in the Indonesian economy by } \\
\text { showing the difference. } \\
\text { 3.2 Formulating joint ventures based on family principles that } \\
\text { have not been consistently realized by business actors in } \\
\text { Indonesia. }\end{array}$ & \\
\hline $\begin{array}{l}\text { 4. Pancasila } \\
\text { Economic Values }\end{array}$ & $\begin{array}{l}\text { 1.1 Analyze the value of caring in the economy } \\
\text { 1.2 Analyze brotherhood values in the economy } \\
\text { 1.3 Analyze the value of nationalism in the economy } \\
\text { 1.4 Analyze the value of economic justice }\end{array}$ & \\
\hline $\begin{array}{l}\text { 5. Rationality: } \\
\text { Economic Needs } \\
\text { and Desires }\end{array}$ & $\begin{array}{l}\text { 5.1 Analyze differences in economic needs and desires } \\
\text { 5.2 Analyze examples of economic needs and desires } \\
\text { 5.3 Selecting economic needs and desires for goods owned so far }\end{array}$ & \\
\hline Understanding $\mathrm{t}$ & he Implementation of Pancasila Economic Values in Daily Life & \\
\hline $\begin{array}{l}\text { 6. Application of } \\
\text { Pancasila } \\
\text { Economic Values } \\
\text { in the Family }\end{array}$ & $\begin{array}{l}.1 \text { Analyze the role of the family in shaping the economic } \\
\text { character of children. } \\
.2 \text { Analyze examples of the application of Pancasila Economic } \\
\text { values in the family. } \\
.3 \text { Evaluating the role of parents in shaping the Pancasila } \\
\text { Economy character in their respective family environments. }\end{array}$ & \\
\hline $\begin{array}{l}\text { 7. Application of } \\
\text { Pancasila } \\
\text { Economic Values } \\
\text { in the } \\
\text { Community }\end{array}$ & $\begin{array}{l}.1 \text { Describe the scope of the community } \\
.2 \text { Analyze examples of the application of Pancasila Economic } \\
\text { values in the Community } \\
.3 \text { Evaluate the Application of Pancasila Economic Values in } \\
\text { the Community Environment. }\end{array}$ & \\
\hline $\begin{array}{l}\text { 8. Application of } \\
\text { Pancasila } \\
\text { Economic Values } \\
\text { in Business }\end{array}$ & $\begin{array}{l}.1 \text { Describe the notion of business based on Pancasila Economic } \\
\text { values } \\
.2 \text { Analyze examples of the application of Pancasila Economic } \\
\text { values in the onion business. } \\
.3 \text { Evaluate the application of Pancasila Economic values for } \\
\text { farmers, distributors and sellers of agricultural medicines } \\
\text { onion in the community. }\end{array}$ & \\
\hline $\begin{array}{l}\text { 9. Cooperative as a } \\
\text { pillar of the } \\
\text { Indonesian } \\
\text { Economy }\end{array}$ & 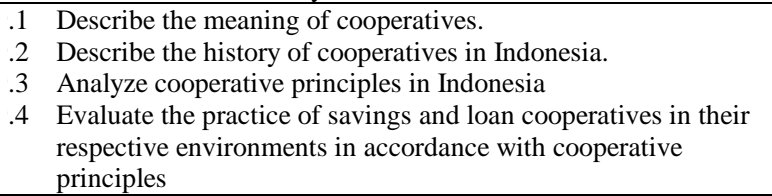 & \\
\hline
\end{tabular}

International Journal of Instruction, January $2021 \bullet$ Vol.14, No.1 


\section{Model Program}

The Pancasila Economic Program Model is integrated with the community and parents shown in Figure below.

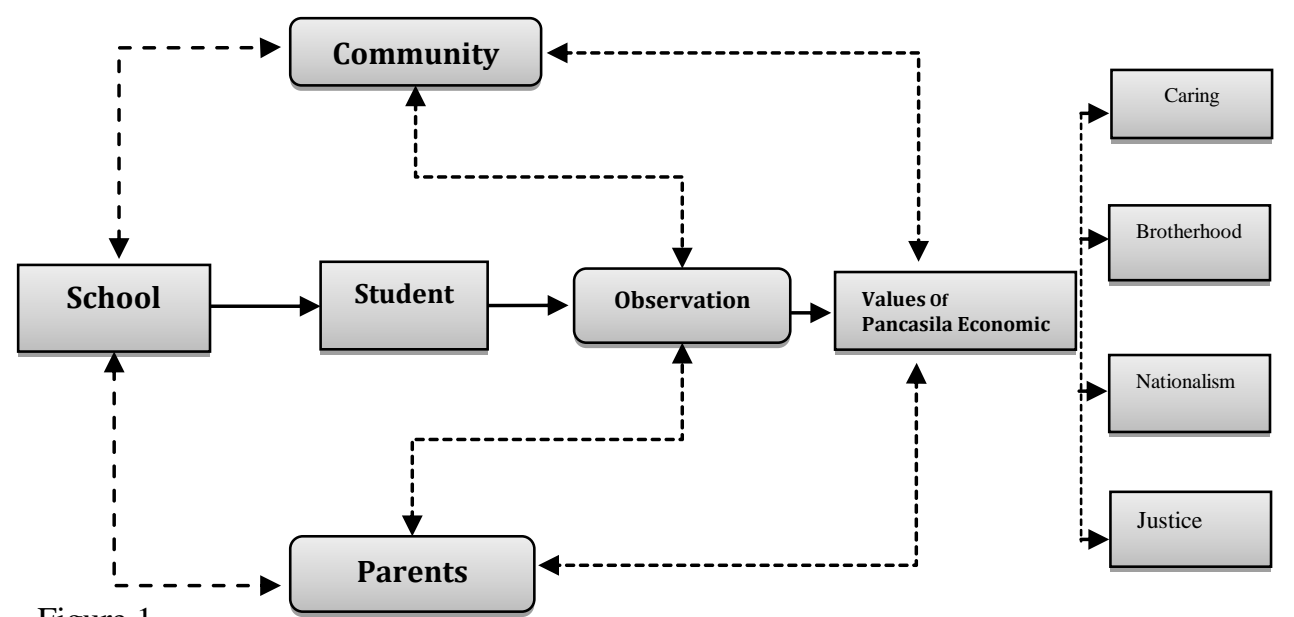

Figure 1

The pancasila economic program model

Figure 1 can be explained that schools must build cooperation with educational leaders in the community and parents of students in planning, implementing and evaluating the economic character literacy program of Pancasila in schools. Students during the learning process are assigned to make direct observations in the community and parents about the application of the economic values of Pancasila and the results of observations become the subject of discussion in class. During the process of observation and discussion groups can increase knowledge, shape the attitudes and economic behavior of students based on Pancasila values in everyday life in the community and family.

\section{METHODS}

\section{Types of Research}

In accordance with the focus of the study, the type of research used is action research using four stages, namely plan, action, observe and reflection (Greenwood, 2017). 
Table 2

Stages of action research

\begin{tabular}{|c|c|c|}
\hline Phase & Action & Challenge \\
\hline Plan & $\begin{array}{l}\text { 1. Results of problem identification and needs analysis through } \\
\text { FGD. } \\
\text { 2. Designing program guides and materials using the steps of } \\
\text { developing (Spector et al., 2014). } \\
\text { 3. Socializing the purpose, objectives and benefits of } \\
\text { participating in the program to students, the community and } \\
\text { parents. } \\
\text { 4. Asking for community collaboration / educational leaders and } \\
\text { parents as. } \\
\text { 5. Deliver and explain the program strategy, namely Type } \\
\text { Student Teams-Achievement Divisions (STAD) and Group } \\
\text { Investigation (GI). } \\
\text { 6. Delivering on the last day of the program all participants will } \\
\text { receive prizes from the facilitator. }\end{array}$ & 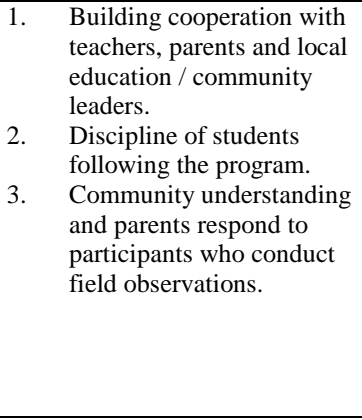 \\
\hline Action & $\begin{array}{l}\text { 1. Carry out program activities according to the guidelines and } \\
\text { material for } 10 \text { meetings ( } 1 \times \text { Meeting @ } 2 \times 45 \text { minutes). } \\
\text { 2. Meeting 1-5 main subjects: Pancasila Economic Concepts, } \\
\text { Internalization of the Pancasila Economy, Joint Business } \\
\text { Based on the Principle of Family, Pancasila Moral Economics } \\
\text { and Rationality: Economic Needs and Desires are taught using } \\
\text { STAD learning strategies. } \\
\text { 3. Meeting 6-10 subject matter: Application of Pancasila } \\
\text { Economic Values in the Family, Application of Pancasila } \\
\text { Economic Values in the Community, Application of Pancasila } \\
\text { Economic Values in Business, and Cooperatives as a Pillar of } \\
\text { the Indonesian Economy are taught using the GI strategy. } \\
\text { 4. GIare carried out by assigning discussion groups to observing } \\
\text { the field of community and family environment regarding the } \\
\text { application of the Pancasila Economic values in daily life. } \\
\text { 5. The results of these observations are subject to group } \\
\text { discussion in the program class. } \\
\text { 6. The facilitator collaborates with economics teachers, the } \\
\text { community and parents of students. }\end{array}$ & 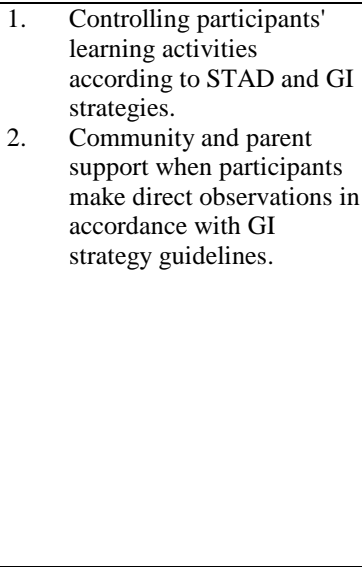 \\
\hline Observe & $\begin{array}{l}\text { An evaluation was conducted to determine the effectiveness of } \\
\text { the program in increasing the Pancasila Economic Character } \\
\text { Literacy of participants by using research instruments: } \\
\text { 1. Essay questions are prepared to measure the Pancasila } \\
\text { Economic Understanding } \\
\text { 2. Questionnaire to measure the pattern of Pancasila Economic } \\
\text { Attitudes } \\
\text { 3. Pancasila Economy Mini Canteen Experiment to measure the } \\
\text { Implementation of Pancasila Economic Values in daily life. }\end{array}$ & $\begin{array}{l}\text { 1. Ensure participants work } \\
\text { independently / alone } \\
\text { 2. Design the simulation } \\
\text { questionnaire carefully so } \\
\text { that it accurately measures } \\
\text { the attitude patterns of the } \\
\text { Pancasila Economy. } \\
\text { 3. Control students / pastors } \\
\text { who buy to get normal data } \\
\text { from the instrument through } \\
\text { the Pancasila Economy Mini } \\
\text { Canteen. }\end{array}$ \\
\hline $\begin{array}{l}\text { Reflectio } \\
\mathrm{n}\end{array}$ & $\begin{array}{l}\text { Conduct a study of the entire set of activities with economic } \\
\text { teachers, parents, educational / community leaders who are } \\
\text { directly involved during the program implementation. This is } \\
\text { done to find out if there are errors / errors in the implementation } \\
\text { of the program to be corrected in the next action. }\end{array}$ & $\begin{array}{l}\text { Uniformity of understanding and } \\
\text { accuracy of facilitators and } \\
\text { collaborators. }\end{array}$ \\
\hline
\end{tabular}

International Journal of Instruction, January $2021 \bullet$ Vol.14, No.1 


\section{Research Subject}

The subjects of this study were students of State Senior High School 2 Soromandi Bima Regency West Nusa Tenggara Province-Indonesia totaling 87 students. The details of the research subject are as follows.

Table 3

Details of research subjects

\begin{tabular}{lllll}
\hline No & Class & Male & Female & Amount \\
\hline 1 & X & 12 & 15 & 27 \\
\hline 2 & XI & 14 & 14 & 28 \\
\hline 3 & XII & 15 & 17 & 32 \\
\hline Amount & & 41 & 46 & 87 \\
\hline
\end{tabular}

Determination of the number of research subjects above is based on several considerations in accordance with the results of the initial observation of researchers:

1. The research subjects are based on the results of the Pancasila Moral Economy Morale questionnaire results and the results of the Pancasila Mini Economy Canteen questionnaire and based on interviews with school canteen management. This means that in Soromandi 2 Public High School, Bima Regency has an average attitude and economic behavior of the Pancasila, which on average is classified as very low.

2. Research subjects are divided into three program groups or classes according to each student's grade level.

\section{Data Collection}

Data collection was carried out using three types of research instruments:

\section{Essay Questions}

The essay question is used to measure the knowledge of the Pancasila Economy manifested in the 1945 Constitution Article 33 and 34 with the following instruction grid.

Table 4

Essay questionnaire

\begin{tabular}{|c|c|c|c|}
\hline No & Material & Indicator & Item \\
\hline 1 & $\begin{array}{ll}\text { Pancasila Economic } \\
\text { Concepts }\end{array}$ & $\begin{array}{l}\text { The characteristics of the Pancasila Economy that are } \\
\text { associated with its implementation. }\end{array}$ & 1 \\
\hline 2 & $\begin{array}{l}\text { Internalization of the } \\
\text { Pancasila Economy }\end{array}$ & $\begin{array}{l}\text { The formulation of the 'Pancasila Economy' system } \\
\text { with the ability to abstract the form of its framework. }\end{array}$ & 1 \\
\hline 3 & $\begin{array}{l}\text { Joint Business Based } \\
\text { on the Principle of } \\
\text { Brotherhood }\end{array}$ & $\begin{array}{l}\text { The joint venture model is based on a family } \\
\text { principle that has not been consistently realized by } \\
\text { business actors in Indonesia. }\end{array}$ & 1 \\
\hline 4 & $\begin{array}{l}\text { Pancasila Economic } \\
\text { Values }\end{array}$ & $\begin{array}{l}\text { The role of Pancasila values in daily life as economic } \\
\text { agents. }\end{array}$ & 1 \\
\hline \multirow[t]{2}{*}{5} & Rationality & Differentiate and select economic needs and desires. & 1 \\
\hline & Amount & & 5 \\
\hline
\end{tabular}




\section{Questionnaire}

The questionnaire was used as an instrument to measure the Pancasila Economic Attitudes of program participants with the following questionnaire grids.

Table 5

Research questionnaire grilles

\begin{tabular}{llll}
\hline No & Material & Indicator & Item \\
\hline 1 & Caring & Share and help each other and not harm others. & 5 \\
\hline 2 & Brotherhood & Participation in mutual assistance activities or social activities. & 4 \\
\hline 3 & Nationalism & Protect each other and promote fellow Indonesian people. & 3 \\
\hline 4 & Justice & $\begin{array}{l}\text { Equally feel the principle of fairness of distribution and } \\
\text { fairness of contribution. }\end{array}$ & 3 \\
\hline & Amount & & 15 \\
\hline
\end{tabular}

\section{Pancasila Economy Mini Canteen}

The canteen sells several types and amounts of daily snacks at the school but no one is guarded and placed in strategic places without any assignment. Buyers will take and pay for themselves by entering the money in the space provided. This experiment is carried out for 30 days (one month) in a row. At the time of coming home from school, the Pancasila Mini Economy Canteen was examined and calculated whether there was a deficit or a surplus between the snacks that had been used up and the amount of money paid. The results of these calculations give a picture of the high or low economic behavior based on Pancasila values in daily life.

\section{Data Analysis}

Using descriptive quantitative analysis with the aim of describing and analyzing the effectiveness of the Pancasila Economic Character Literacy Program which is learned from the knowledge, attitudes, and behavior of the Pancasila value-based economy in daily life. The rules of decision making are based on the interval classes below.

Table 6

Program effectiveness intervals

\begin{tabular}{|c|c|c|c|c|}
\hline \multirow[t]{2}{*}{ No } & \multicolumn{2}{|c|}{$\begin{array}{l}\text { Knowledge and Economic Attitudes of the } \\
\text { Pancasila }\end{array}$} & \multicolumn{2}{|c|}{ Pancasila Economic Behavior } \\
\hline & Interval & Category & Interval & Category \\
\hline 1 & $50-59$ & Ineffective & $\geq-2$ (deficit) & Ineffective \\
\hline 2 & $60-69$ & Less effective & -1 (deficit) & Less effective \\
\hline 3 & $70-79$ & Effective & 0 (equilibrium) & Effective \\
\hline 4 & $80-90$ & Very effective & $\geq+1$ (a surplus) & Very effective \\
\hline
\end{tabular}

Source: Adapted from (Decoster \& Hall, 2001)

\section{Decision:}

1. What is the success of this program if $\geq 75 \%$ of Pancasila Economic Knowledge is in the $\geq$ effective category. 
2. What is the success of the program if $\geq 70 \%$ of Pancasila Economic Attitudes are in the $\geq$ effective category.

3. What is the success of this program if the Pancasila Economic Behavior in the aggregate balance of transactions is in the category of $\geq$ equilibrium

\section{FINDINGS}

During the research activities of 87 students, there were 3 people who did not complete the entire program with the reason to focus on helping parents, and the information was confirmed by each parent so that they were excluded as program participants. The number of program participants was 84 people. The results of the study are as follows.

\section{Program Effectiveness Against Pancasila Economic Knowledge}

After conducting data analysis activities with the help of the SPSS program on Pancasila Economic Knowledge, participants can be identified as follows.

Table 7

Knowledge of pancasila economics

\begin{tabular}{|c|c|c|c|c|}
\hline \multirow{2}{*}{ No } & \multicolumn{4}{|c|}{ Knowledge of Pancasila Economics } \\
\hline & Interval & Category & Frequency & Percent \\
\hline 1 & $50-59$ & Ineffective & - & - \\
\hline 2 & $60-69$ & Less effective & 9 & 11 \\
\hline 3 & $70-79$ & Effective & 60 & 71 \\
\hline 4 & $80-90$ & Very effective & 15 & 18 \\
\hline & Amount & & 84 & 100 \\
\hline
\end{tabular}

Source: Summary of SPSS Output Descriptive Analysis, 2019

Table 7 shows that 9 people or $11 \%$ are in the ineffective category (60-69), then 60 people or $71 \%$ are in the effective category (70-79) and 15 people or $18 \%$ get a score of the very effective category (80-90). So the Pancasila Economic Character Literacy Program in terms of the Pancasila Economic Knowledge was declared successful because $>75 \%$ of participants were in the effective category.

\section{Program Effectiveness Against Pancasila Economic Attitudes}

The results of the analysis with the help of the SPSS program on Pancasila Economic Attitudes of participants are known as follows.

Table 8

Pancasila economic attitudes

\begin{tabular}{lllll}
\hline \multirow{2}{*}{ No } & \multicolumn{2}{l}{ Pancasila Economic Attitude } & & \\
\cline { 2 - 5 } & Interval & Category & Frequency & Percent \\
\hline 1 & $50-59$ & Ineffective & 7 & 8 \\
\hline 2 & $60-69$ & Less effective & 15 & 18 \\
\hline 3 & $70-79$ & Effective & 54 & 65 \\
\hline 4 & $80-90$ & Very effective & 8 & 9 \\
\hline & Amount & & 84 & 100 \\
\hline
\end{tabular}

Source: Summary of SPSS Output Descriptive Analysis, 2019 
Table 8 shows that there are 7 people or $8 \%$ are in the ineffective category (50-69). 15 people or $18 \%$ are in the less effective (60-69), then 54 people or $65 \%$ are in the effective category (70-79) and 8 people or $9 \%$ are in the very effective category (80-90). So the Pancasila Economic Character Literacy Program in terms of the Pancasila Economic Attitude of the participants was declared successful because $>70$ participants were in the effective category.

\section{Program Effectiveness Against Pancasila Economic Behavior}

The results of the descriptive analysis of Pancasila Economic Behavior in daily life are reviewed from the results of the Pancasila Economy Mini Canteen for 30 consecutive days the results are known as follows.

Table 9

Pancasila economic behavior

\begin{tabular}{lllll}
\hline \multirow{2}{*}{ No } & \multicolumn{2}{l}{ Pancasila Economic Behavior } & & \\
\cline { 2 - 5 } & Interval & Category & Frequency & Percent \\
\hline 1 & $\geq-2$ (deficit) & Ineffective & 3 & 10 \\
\hline 2 & -1 (deficit) & Less effective & 5 & 16 \\
\hline 3 & 0 (equilibrium) & Effective & 11 & 37 \\
\hline 4 & $\geq+1$ (a surplus) & Very effective & 11 & 37 \\
\hline Amount & & 30 & 100
\end{tabular}

Source: Summary of SPSS Output Descriptive Analysis, 2019

Table 9 shows that for 30 days (one month) the expansion through the Pancasila Mini Economy Canteen, the results for 3 days experienced a device of $-5 \%$ were in the ineffective category. Then for 5 days, the expatriates experienced a deficit of $1 \%$. Furthermore, for 11 days experienced equilibrium, and 11 days also experienced a surplus of $+6 \%$. It can be concluded that the Pancasila Economic Character Literacy Program in terms of the Pancasila Economic Behavior is declared successful because in the aggregate the transaction deficit is in the equilibrium category.

\section{Reflection}

There are several challenges faced by researchers or facilitators, namely: (1) understanding of the community, especially business people when being informants of program participants at the time of observation; (2) understanding and caring of parents needs to be increased again because there are some participants who have difficulty when observing their parents regarding the application of economic values in the family. Before the program is implemented there must be a literacy activity on the role of the community and parents on the effectiveness of the program.

\section{DISCUSSION}

The Pancasila Economic Character Literacy Program has proven to be effective in increasing the Pancasila Economic Knowledge which is manifested in the 1945 Constitution Articles 33 and 34 covering the ability to: (1) analyze concepts and evaluate the characteristics of the Pancasila Economy that have not been consistently realized by the Indonesian people; (2) describes the formulation of "Pancasila 
Economy" System 'with the ability to abstract the form of its framework. This shows that participants already have a theoretical understanding of the values contained in the precepts of the Pancasila from the perspective of economics; (3) describe the types of business actors in Indonesia and be able to evaluate the forms of joint business implementation based on the principle of kinship for all businesses in Indonesia in accordance with the orders of the 1945 Constitution Article 33 Paragraph 1, in the form of its implementation through partnership movements, monopoly prohibitions and unfair business competition; (4) analyze the role of Pancasila values of economic life; and (5) can evaluate rational economic behavior by distinguishing between economic needs and desires.

Pancasila Economic Knowledge can be useful for participants both in the short and long term, "they" are the legitimate heirs of this nation, and therefore their mindset must be filled with Pancasila values because most people's attitudes and actions are based on consideration of knowledge complex including in determining economic choices or decisions. In other words, knowledge has an influence on one's economic attitudes and decisions (Lewis \& Scott, 2000). Complex knowledge has a role that is consistent with one's attitudes (Fabrigar et al., 2006).

The Pancasila Economic Character Literacy Program, in addition to effectively increasing knowledge, has also been proven effective in improving children's economic attitudes, including (1) caring, (2) brotherhood, (3) nationalist; and (4) economic justice. These values in their application do not stand alone but are a unified whole. Honest economic actors mean having care for other economic actors. Concern for having the belief that other people are like family and even like yourself. Brit her hood value implies that all economic actors are considered as blood relatives because it is very immoral if there is some one who can cheat on his own brother (Swasono, 2015). This situation also shows indicators of mutual protection and advancement and raising each other among the people of Indonesia (nationalists). If everything is done just and equitable economic prosperity for all the people of Indonesia (economic justice) will be easily achieved.

Nationalism is broadly meaningless against foreigners, but foreign independence does not dominate the control of resources in Indonesia. According (Swasono, 2015; Tjakrawerdaja \& Soedarno, 2017) nationalism has the meaning: (1) it must be realized that the aim is to carry out Indonesian development not just development in Indonesia; (2) building to assert that they are masters in their own country and not become domestic servants; (3) prioritizing national interests without ignoring global responsibilities; (4) may not be anti-foreign, but the foreign economy cannot dominate the national economy; (5) our friendly nation likes to cooperate with any foreigners, at the same time we must emphasize that cooperation is not a place to sacrifice national interests or national economic deprivation; and (6) people's sovereignty is a national doctrine that must be upheld and may not be replaced by market conditions. Nationalism for economic actors is also applied as follows: (1) for consumers by maximizing the utilization/use of domestic products. (2) government policies prioritizing the interests of the people of Indonesia; and (3) building cooperation with business actors, especially 
business people in the people's economy (Micro, Small Business and Managing and Cooperative).

The positive attitude of the participants becomes an indicator of behavior that puts forward the values of the Pancasila Economy in daily life. Research result a person's attitude plays an important role in behavioral tendencies that are relatively long-lasting toward social objects, groups, events, or symbols (Ajzen et al., 2011; Hogg \& Vaughan, 2010). Attitude is also a predictor of a person's behavior; good or bad behavior is moderated by situational factors, personality traits, or the characteristics of the attitude itself. This reinforces the findings of the study that the Pancasila Economic Character Literacy Program is proven effective in terms of economic behavior based on Pancasila values. So knowledge, attitudes and economic behavior are interrelated series; knowledge can form attitudes while attitudes will be activated in the form of behavior. Research result when someone has an attitude to be activated in behavior, attitude is often a guide, and when faced with behavior someone often considers how complex knowledge is and attitudes and behaviors tend to be influenced by the content and structure of knowledge (Albarracin \& Johnson, 2019; Fabrigar et al., 2006).(Fabrigar et al., 2006)

Overall the results of this study support previous studies that various types of literacy programs that are integrated with the community have proven to be effective in increasing knowledge, financial attitudes of children and adolescents, increasing selfefficacy and helping students deal with various problems and challenges (Amagir et al., 2018, 2019; Leptien, 2015; Vaknin \& Bresciani, 2013).

\section{CONCLUSIONS}

Economic references taught at all levels of education in Indonesia, including in several other countries, are dominated by neoclassical theories that prove to be incompatible with the economic values of Pancasila, including caring, brotherhood, nationalism, and economic justice. The Pancasila economic character literacy program is integrated with the community and parents through cooperative learning of the Student Study Achievement Division (STAD) and Group Investigation (GI) can improve students' knowledge, attitudes and economic behavior based on Pancasila values. Therefore educational institutions do not only focus on economic knowledge but must be balanced with fostering the ideological value-based economic character so that students do not lose their identity as a generation of people who have an ideological identity.

\section{ACKNOWLEDGEMENT}

The author (s) received research funding support from the "Kementerian Riset dan Teknologi Pendidikan Tinggi (KEMENRISTEKDIKTI), Indonesia".

\section{REFERENCES}

Adams, E. C. (2019). Economics and The Civic Mission of Social Studies Education: Two Critiques of Neoclassicism. Citizenship, Social and Economics Education, 18, 1632. doi:10.1177/2047173419841915 
Ajzen, I., Joyce, N., Sheikh, S., \& Cote, N. G. (2011). Knowledge and the Prediction of Behavior: The Role of Information Accuracy in the Theory of Planned Bhavior. Basic and Applied Social Psychology, 33, 101-117. doi:10.1080/01973533.2011.568834

Albarracin, D., \& Johnson, B. T. (2019). The Handbook of Attitudes (2nd ed). [eBook]. Retrieved from https://www.amazon.com/Handbook-Attitudes-Basic-Principles2nd/dp/1138648264

Amagir, A., Groot, W., Maassen van den Brink, H., \& Wilschut, A. (2018). A Review of Financial-Literacy Education Programs for Children and Adolescents. Citizenship, Social and Economics Education, 17, 56-80. doi:10.1177/2047173417719555

Amagir, A., Groot, W., Maassen van den Brink, H., \& Wilschut, A. (2019). SaveWise: The Design of F financial Education Program in The Netherlands. Citizenship, Social and Economics Education, 182, 100-120. doi: 10.1177/2047173419870053

Arinda, Y., Wilujeng, I., \& Kuswanto, H. (2019). The Application Group Investigation (GI) Learning Model assisted Phet to Facilitate Student Scientific Work Skills. International Journal of Educational Research Review, 254-261. doi:10.24331/ijere.518069

Badan Pusat Statisitik. (2019, July 15 ). Gini Ratio Maret 2019 Tercatat Sebesar 0,382.

Gini Ratio Maret 2019 Tercatat Sebesar 0,382. Retrieved from https://www.bps.go.id/pressrelease/2019/07/15/1630/gini-ratio-maret-2019-tercatatsebesar-0-382.html

Bauman, Y., \& Rose, E. (2011). Selection or Indoctrination: Why do Economics Students Donate Less Than the Rest? Journal of Economic Behavior and Organization, 79, 318-327. doi: 10.1016/j.jebo.2011.02.010

Boylan, M. (2015). Learning Economics: A Cautionary Tale. Sociological Forum, 30, 234-239. doi: 10.1111/socf.12154

Decoster, J., \& Hall, G. P. (2001). Introductory Statistics. In Designing Capable and Reliable Products, 277-287. [eBook]. Retrieved from http://www.stathelp.com/intro.pdf

Deliarnov. (2012). Perkembangan Pemikiran Ekonomi (2nd ed.). Jakarta: Rajawali Perrs.

Eisler. (2010). Economics as If Caring Matters. Challenge, 53, 43-67. doi:10.2753/0577.

Etzioni, A. (2015). The Moral Effects of Economic Teaching. Sociological Forum, 30, 228-233. doi:10.1111/socf.12153

Fabrigar, L. R., Petty, R. E., Smith, S. M., \& Crites, S. L. (2006). Understanding Knowledge Effects on Attitude-Bbehavior Consistency: The Role of Relevance, Complexity, and Aamount of Knowledge. Journal of Personality and Social Psychology, 90, 556-577. doi:10.1037/0022-3514.90.4.556 
Faravelli, M. (2007). How Context Matters: A Survey Based Experiment on Distributive Justice. Journal of Public Economics, 91, 1399-1422. doi:10.1016/j.jpubeco.2007.01.004

Fölster, C. A. (2013). He New Rise Of Economic Nationalism In Transatlantic Trade Relations. Journal of Chemical Information and Modeling, 53, 1689-1699. doi: 10.1017/CBO9781107415324.004

Gasper, D. (2008). From "Hume"s Law' to Problem- and Policy-Analysis For Human Development. Sen After Dewey, Myrdal, Streeten, Stretton and Haq. Review of Political Economy, 20, 233-256. doi: 10.1080/09538250701819701

Greenwood, D. J. (2017). Action Research. In Qualitative Methodologies in Organization Studies, 3, 75-98. doi:10.1007/978-3-319-65217-7_5

Hanafiah, K. (2016). The Superiority Factors of American Management Education: Evidence from China. Journal of Administrative Management, Education and Training (JAMET), 12, 69-91.

Hogg, M. A., \& Vaughan, G. M. (2010). Essentials of Social Psychology, (3nd ed). [eBook]. Retrieved from http://www.yanchukvladimir.com

Ilyas, M., \& Tahir, T. (2015). The Implementation of Pancasila Economic System in Economic Learning At Faculty of Economics State University of Makassar. IOSR Journal of Economics and Finance Ver. III, 6, 2321-5933. doi:10.9790/5933-06636669

Jaelani. (2016). Pancasila Economic and The Challenges of Globalization and Free Market In Indonesia. Journal of Economic and Social Thought Articles, 3. 241-251. Retrieved from https://papers.ssrn.com

Jamil, R. (2015). Agents of American hegemony in Management Education: Evidence From Malaysia. International Journal of Management Education, 13, 302-315. doi: 10.1016/j.ijme.2015.09.002

Jayaraman, J. D., \& Jambunathan, S. (2018). Financial Literacy Among High School Students: Evidence From India. Citizenship, Social and Economics Education, 17, 168187. doi: $10.1177 / 2047173418809712$

Leptien, J. R. (2015). Aligning Needs, Expectations, and Learning Outcomes to Sustain Self-Efficacy Through Transfer Learning Community Programs. (41-55). [eBook]. Retrieved from https://onlinelibrary.wiley.com

Lewis, A., \& Scott, A. J. (2000). The Economic Awareness, Knowledge and Pocket Money Practices of a Sample of UK Adolescents: A Study of Economic Socialisation and Economic Psychology. Citizenship, Social and Economics Education, 4, 34-46. doi: $10.2304 /$ csee.2000.4.1.34

Lucey, T. A. (2019). Examining a measure of spiritual capital: Perceptions of business and education majors. Citizenship, Social and Economics Education, 18, 3-15. doi: $10.1177 / 2047173418823543$ 
Morgan, J. W. (2013). Ethics, Economics and Higher Education: A Comment. Citizenship, Social and Economics Education, 12, 129-135. doi: 10.2304/csee.2013.12.2.129

Mubyarto. (2004). Pendidikan Ekonomi Kita. Yogyakarta: Universitas Gajah Mada.

Neal, M., \& Finlay, J. L. (2008). American Hegemony and Business Education in the Arab World. In Journal of Management Education 3, 38-83. doi: $10.1177 / 1052562906297075$

Riccio, L. L., \& Hannon, C. L. (2002). The Role of Education, Community Integration and Arts Enterprise in Developing Entrepreneurial Skills in Adolescent at-Risk Populations. Citizenship, Social and Economics Education, 5, 180-192. doi: 10.2304/csee.2002.5.3.180

Schmidtke, C., \& Chen, P. (2012). Philosophy of Vocational Education in China: A Historical Overview. Journal of Philosophy of Education, 46, 432-448. doi:10.1111/j.1467-9752.2012.00859.x

Singer, T., \& Snower, D. J. (2010). Caring Economics A New Approach to Prosperity Background: Approaching Prosperity through Traditional Economics. In Caring Economics (pp. 1-10). Retrieved from https://www.ineteconomics.org

Spector, J. M., Merrill, M. D., Elen, J., \& Bishop, M. J. (2014). Handbook of Research on Educational Communications and Technology: Fourth Edition. Handbook of Research on Educational Communications and Technology: (4nd ed). [eBook]. Retrieved from https://www.springer.com.

Subroto, W. T. (2015). Revitalization of Pancasila Economic System in the Globalization Era. International Journal of Economics and Financial Issues, 5, 860 867. Retrieved from https://www.researchgate.net/

Swasono, S.E. (2015). Keindonesiaan: Demokrasi Ekonomi, Keberdaulatan dan Kemandirian (1st ed.). Jakarta: UST-PRESS.

Tjakrawerdaja \& Soedarno. (2017). Sistem Ekonomi Pancasila (1st ed.). Depok: Rajawali Pers.

Vaknin, L. W., \& Bresciani, M. J. (2013). Implementing Quality Service-Learning Programs in Community Colleges. Community College Journal of Research and Practice, 37, 979-989. doi: 10.1080/10668926.2010.515515

Word Bank. (2019). Inequality and Shared Prosperity: Overview. The Word Bank. Retrieved from https://www.worldbank.org/en/topic/isp

World Bank. (2015). Ketimpangan yang Semakin Lebar. Retrieved from http://documents.worldbank.org/curated/en/870151468197336991/pdf/101668-

BAHASA-WP-PUBLIC-Box394818B-Executive-Summary-Indonesias-Rising-

Divide.pdf 
Wyk, M. M. van. (2012). The Effects of the STAD-Cooperative Learning Method on Student Achievement, Attitude and Motivation in Economics Education. Journal of Social Sciences, 33, 261-270. doi: 10.1080/09718923.2012.11893104

Yuliani, N. (2019). The Role of Student Teams Achievement Divisions (STAD) in Improving Student's Learning Outcomes. Classroom Action Research Journal, 3, 8-15. doi: 10.17977/um013v3i12019p008 